\title{
Joining the UN Family?
}

\section{Explaining the Evolution of IOM-UN Relations}

\author{
Megan Bradley | ORCID: 0000-0001-8309-5866 \\ Department of Political Science, McGill University, Montreal, QC, Canada \\ megan.bradley@mcgill.ca
}

\begin{abstract}
The International Organization for Migration (IOM) became a related organization in the United Nations system in 2016, and has rebranded itself as the "UN Migration Agency." This article examines the drivers and significance of IOM's new relationship with the UN. It traces the evolution of the IOM-UN relationship, and the processes that led to IOM becoming a related organization. While some contend that IOM is still not really part of the UN system, through an analysis of the status and political positioning of related organizations this article demonstrates that, as a related organization, IOM is indeed now part of the UN system. It argues that IOM's work with forced migrants in the humanitarian sector played a pivotal role in enabling this shift, and considers its implications.
\end{abstract}

\section{Keywords}

International Organization for Migration - United Nations - migration - humanitarianism - related organizations

\section{Introduction $^{1}$}

At the 2016 UN Summit for Refugees and Migrants, UN Secretary-General Ban Ki-moon and International Organization for Migration (IOM) Director Gen-

1 This work was supported by the Social Sciences and Humanities Research Council of Canada. The author thanks her colleagues and reviewers for their comments. 
eral Bill Swing signed a new Agreement Concerning the Relationship between the United Nations and the International Organization for Migration, which repositioned IOM as a "related organization" in the UN system. According to Swing, through this agreement the "United Nations now has a 'UN Migration Agency.'"2 Many were surprised by the quick negotiation of this agreement, which challenges the assumption that IOM's advantage was its position outside the UN system, unencumbered by principles or a formal protection mandate. ${ }^{3}$

This article examines the evolution of UN-IOM relations, focusing on the political processes and dynamics that led to IOM becoming a related organization in the UN system, which remains an underexamined development. ${ }^{4}$ Some question whether IOM, as a related organization, is really part of the UN system. ${ }^{5}$ In contrast, I demonstrate that IOM is now functionally in the UN system, and examine divergent views on this development held by IOM, UN, and Member State officials. Although I consider its legal dimensions, I am primarily concerned with the UN system as a political system, understood broadly as actors in "a nexus of relationships, both conflictual and cooperative, generated by common problems and the need to deal with them."' Through the 2016 agreement, IOM leaders aimed to protect - and expand — the agency's "turf" and rectify what they saw as an imbalanced situation in which IOM had become entangled with the UN and dependent on it, without the advantages of membership in the system. Meanwhile, UN leaders recognized Member States' increasing support for IOM's entry into the UN system; the need for increased operational capacity on migration within the UN system; and the possibility that by bringing IOM into the system, it could be more effectively prevailed on to respect the UN's principles. IOM's entrance into the UN system seemed highly unlikely until 2015, when factors including the perceived global migration crisis kickstarted rapid negotiations. However, this change must be situated in the longer history of collaboration and conflict in UN-IOM relations, with cooperation in humanitarian affairs serving as a pivotal foundation for this shift.

After providing some background on IOM, I sketch the history of IOM-UN relations, and explain the status of related organizations. I then map out the

2 Swing 2016.

3 On this assumption see, for example, Ashutosh and Mountz 2011; Georgi 2010; Pécoud 2018.

4 Most examinations focus on legal analysis of the 2016 agreement, rather than political and institutional factors precipitating the change. See, for example, Guild, Grant, and Groenendijk 2017; Goodwin-Gill 2019; Cullen 2019. For a discussion related to the arguments raised here, see Bradley 2020.

5 See, for example, Pécoud 2018; Goodwin-Gill 2019; Guild, Grant, and Groenendijk 2017; Cullen 2019 .

6 Gregg and Bakin 1968, 4; White 2002, 11. 
drivers and processes surrounding IOM's entry into the UN system, and analyze the 2016 agreement, including IOM's designation as "non-normative." I conclude by analyzing some of its early implications. My argument is based on analysis of IOM and UN policies, archival research at UN headquarters, and sixty-six in-depth interviews undertaken between 2015 and 2020 with IOM officials and Member State representatives (including participants in the IOMUN negotiations), independent experts, human rights advocates, and representatives of humanitarian nongovernmental organizations (NGOs) and UN agencies. ${ }^{7}$ Interview data were analyzed through a grounded coding process that identified key themes and concerns, which inform my argument. To be clear, my aim is not to assess whether these developments are morally or politically laudable, or to evaluate IOM's contentious behavior regarding migrants' rights protection. ${ }^{8}$ Rather, my goal is to explain how and why the UN-IOM relationship evolved, such that IOM was able to join the UN system as a related organization.

\section{Background}

Created in 1951 as the Provisional Intergovernmental Committee for the Movement of Migrants from Europe (PICMME) to help settle Europe's post-World War II displaced and "surplus population," the agency's name changed several times before emerging in 1989 as IOM, a global agency working under the banner of managed migration "for the benefit of all." ${ }^{9}$ On US insistence, the agency was established outside the UN system with no communist Member States. ${ }^{10}$ As its work in Europe waned, the agency subsisted on a shoestring, with an amorphous mandate and limited membership. In the 1990s, however, IOM began growing with a "projectization" model whereby states effectively contract IOM to provide different services. IOM's membership skyrocketed from 67 Member States in 1998 to 173 in 2020 , while its budget swelled from $\$ 242.2$

These included twenty-one IOM officials; thirteen member state representatives; thirteen human rights advocates working with $\mathrm{UN}$ agencies and NGOs; twelve representatives of humanitarian agencies (NGO s and UN actors such as UNHCR and OCHA); and six independent experts including former UN officials. To facilitate discussion of sensitive issues, interviewees participated anonymously and have been assigned a number in lieu of identifying details.

8 For important critiques see, for example, Andrijasevic and Walters 2010; Ashutosh and Mountz 2011; Hirsch and Doig 2018.

9 Ducasse Rogier 2001, 6-7.

$10 \quad$ Élie 2010. 
million in 1998 to over $\$ 2$ billion in 2020. With over 13,80o employees, IOM is now among the world's largest international organizations (IOs).11

Scholarship on IOM remains scant. Existing research focuses primarily on contested international migration management activities such as so-called assisted voluntary returns. However, humanitarian responses to displacement-themselves a means of managing migration—now account for the majority of IOM's budget and field presence. ${ }^{12}$ Internally displaced persons are by far IOM's largest "beneficiary" group, but the agency also plays major roles in relation to refugees and migrants in crises. Importantly, IOM's constitution does not legally define the populations with whom it is to work, and it has no formal mandate to protect the rights of the migrants (internal or international). Increasingly, IOM employs human rights rhetoric and its entry into the UN system was preceded by the development of institutional policies and frameworks that tie it, if loosely, to human rights and humanitarian standards, including IOM's 2012 Migration Crisis Operational Framework, 2015 Migration Governance Framework, and 2015 Humanitarian Policy.

What is distinctive of IOM as an IO? IOM has fostered a reputation for flexibility, efficiency, logistical proficiency, and operational capacity, and has expanded by strategically (or opportunistically) filling gaps in international responses to migration, particularly in emergencies. Most IOs depend on donors, and present themselves as serving members. Yet IOM is remarkably deferential to its members, and reliant on project-based funding. This has fueled concerns that it is driven by a "sell, sell, sell mentality." ${ }^{13}$ Coupled with its competitive bent and lack of a formal protection mandate, these characteristics have at times fostered mistrust and conflict with UN agencies, especially the Office of the UN High Commissioner for Refugees (UNHCR).

The UN-IOM relationship is multidimensional, encompassing IOM's connections to players including the Secretariat and UNHCR, and its position in the $\mathrm{UN}$ system overall. Rapprochement alongside competitiveness and tension is a constant refrain in IOM-UN relations. Amidst suspicion and competition, IOM and UNHCR in particular have worked closely, including on returns. ${ }^{14}$ By 2016 ,

\footnotetext{
11 IOM 2019a, 2; Bradley 2017, 97.

12 Martin 2014, 143; Bradley 2017.

13 Interview, humanitarian actor 7 (UN), December 2015.

14 Élie 2010; Koch 2014.
} 
IOM staff already worked under UN salary scales, pension schemes, security systems, and the UN Staff Rules and Regulations; IOM had memorandums of understanding and cooperation agreements with dozens of UN bodies, was a de facto member of many UN humanitarian country teams, and accessed various UN funding mechanisms. In many quarters, this created an impression of IOM as "quasi-UN," an amorphous status with frustrations and benefits for both the UN and IOM. ${ }^{15}$

\subsection{IOM-UN Relations during the Cold War}

IOM's connections to the UN system trace back to 1951, when PICMME (renamed the Intergovernmental Committee for European Migration [ICEM]) inherited the International Refugee Organization's ships to transport refugees and other migrants. Notwithstanding early collaborations such as the $195^{2}$ creation of a joint UNHCR-ICEM office in Hong Kong, UN-ICEM tensions emerged early, especially regarding mandates and coordination. For example, in a 1953 letter to ICEM Director General Hugh Gibson, UN Secretary-General Dag Hammarskjöld flags the "danger of duplication and overlapping."16 In 1956 Hammarskjöld received reports that ICEM-UNHCR relations were "very strained," with the UNHCR objecting to "ICEM's intervention in what he considers to be his responsibilities."17 In early 1957, however, some senior UN officials reflected that previously "difficult" relations with ICEM had "become very close owing particularly to their wholehearted cooperation with the High Commissioner for Refugees on Hungarian refugee questions."18 Such interspersed conflict and rapprochement continued as the decades passed.

ICEM officials expressed early interest (contrary to Member States' preferences) in joining the UN, and were rebuffed by skeptical UN counterparts. For instance, in a 1953 letter to Hammarskjöld, senior UN official Martin Hill indicates that ICEM Deputy Director Pierre Jacobsen raised "the possibility of more formal relationships between ICEM and the UN," and "promot[ing] a movement within ICEM to request Specialized Agency status with the United Nations or some special form of relationship, giving ICEM United Nations recognition and standing."19 Hill warned this would be unlikely given "the difficulty of reconciling the ICEM constitution with the UN Charter, [and] the political objections that would no doubt arise from certain quarters"-a

\footnotetext{
15 Interview, Member State official 2, December 2016.

16 Hammarskjöld 1953 .

17 Hill 1956.

18 Cordier 1957.

19 Hill 1953.
} 
veiled reference to ICEM's exclusion of communist states. ${ }^{20}$ Hill advised Hammarskjöld to "keep relationships with ICEM as informal and uncrystallised as possible," arguing that ICEM "rests indeed upon an arbitrary and anti-UN attitude taken by the US Congress, which we may well hope will one day be reversed." 21

\subsection{Post-Cold War Dynamics}

While such skepticism persisted, IOM-UN rapprochement accelerated in the early 199os as the end of the Cold War, the outbreak of several "complex emergencies," and institutional reforms within IOM fueled the organization's growth, particularly in the humanitarian sector. For example, in 1992, IOM obtained observer status in the UN General Assembly, and joined the InterAgency Standing Committee (IASC) (the primary humanitarian coordination venue for UN actors and partners) as a standing invitee. In 1993, IOM became eligible for funding through the UN's Central Emergency Response Fund.

An important 1995 policy document, IOM Strategic Planning: Toward the Twenty-first Century, emphasized this cooperation but also growing tensions, stating that IOM "operates as a member of the team of multilateral agencies which forms the global emergency response network," but its contributions and expertise were not appropriately acknowledged or respected by the UN. ${ }^{22}$ IOM argued that it "should receive reciprocal respect and support for its role and functions in the field of migration ... this requires IOM Member States, which are also members of the United Nations organs and agencies, to establish and make clear such a policy decision" and resolve debates on "the formal ties that do or should bind IOM and the United Nations system."23 In light of these concerns, UN Secretary-General Boutros Boutros-Ghali and IOM Director General Jim Purcell signed the 1996 Cooperation Agreement between the UN and IOM. The agreement emphasized the need for strengthened, collaborative responses to displacement and humanitarian crises, again underscoring the central role of cooperation in the humanitarian sphere to the development of UN-IOM relations. It promotes collaboration on joint initiatives; technical and administrative arrangements; training; meetings; and sharing documentation, research and statistics.

Despite this agreement, tensions increased when the 2002 Report of the Secretary-General, Strengthening the United Nations: An Agenda for Further

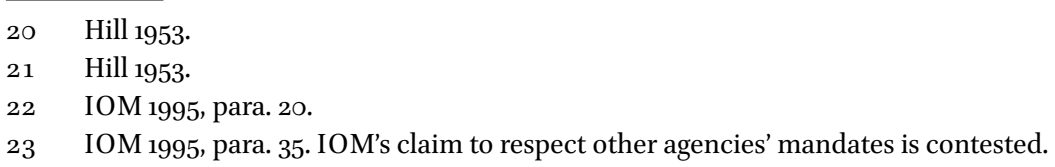


Change, highlighted migration as a key issue meriting $\mathrm{UN}$ attention. ${ }^{24} \mathrm{UN}$ offcials identified options to improve migration cooperation, including creating a new migration agency or transforming IOM into a specialized agency. Some senior IOM officials supported the latter option, but wanted IOM to steer this discussion. ${ }^{25}$ Therefore, on Director General Brunson McKinley's urging, the IOM Council created a Working Group on Institutional Arrangements for Member States to explore the issue. In discussing the issue, the IOM administration attempted to present itself as impartial, stressing:

The IOM Administration is not campaigning either for or against a change. IOM has done well by our independence and can continue to prosper as we are. Alternatively, under the right arrangements - ones that preserve our Constitution, our individuality and our special characteristics - I believe we could also prosper as part of the United Nations system. ${ }^{26}$

Yet the administration shaped the conversation by presenting three main options to the Working Group: 1) becoming a specialized agency; 2) strengthening relations with the $\mathrm{UN}$ while staying outside the system ("improved status quo"); and 3) no action. ${ }^{27}$ The administration tacitly promoted the specialized agency option, but in 2003 most IOM members favored improving the status quo. ${ }^{28}$ To this end, UN-IOM collaboration improved on some fronts, depending significantly on the individuals involved.

In 2007 the IOM leadership revived the conversation, arguing more directly for a new relationship with the UN, contending that existing arrangements were unfair, inefficient, and incoherent, resulting in institutional overlaps and missed opportunities. ${ }^{29}$ IOM's members were again unpersuaded. McKinley therefore proposed a workaround, asking UN Secretary-General Ban Ki-moon to invite IOM to join the UN Development Group (UNDG) and attend the Chief Executives Board for Coordination (CEB), the UN system's highest-level coordination forum, contending this would fill an operational and policy gap,

\footnotetext{
24 UNSG 2002. Historically, the UN avoided discussion of migration issues in part owing to their divisive nature. Initiatives such as the UN High-Level Dialogues on migration and development helped allay this concern. See Martin 2014, 235-269.

25 IOM 2003, Annex III, paras. 4-7.

26 McKinley 2002.

27 IOM 2003, Annex I, paras. 6-7.

28 IOM 2003, Annex III, para. 33.

29 IOM 2007, paras. 66-68.
} 
"deepen mutual understanding and encourage cooperation." ${ }^{30}$ Ban disagreed, asserting these bodies were restricted to UN programs, funds, and specialized agencies. ${ }^{31}$ Technically this was incorrect as related organizations like the International Atomic Energy Agency (IAEA) belonged to the CEB, and IOM joined in 2016. Yet Ban's decision effectively limited IOM's integration into the UN system without recasting the relationship.

\subsection{Revived Negotiations}

Structured discussions of IOM-UN relations were set aside following Swing's election as Director General in 2008. Instead, Swing focused on mending and strengthening connections with UN counterparts, attempting to (re)cast IOM as a more conscientious and reliable partner. While some tensions persisted, many suggest UN-IOM relations improved in this period, prompting some IOM senior officials to conclude that "there is nothing more we can improve. ... We have reached the limit" of the "improved status quo" arrangement. ${ }^{32}$

Under Swing's guidance, the Working Group reconvened in 2014; by 2015, the perceived refugee and migration crisis brought fresh urgency to strengthening international responses to migration and displacement. Many states regarded IOM as an important partner on these issues, and saw the UN's patchwork of engagement on migration as untenable. While momentum grew to have a migration-focused agency in the UN system, donors were unwilling to fund a new organization, or dramatically revamp existing agencies. Accordingly, the IOM Council passed Resolution 1309 on 24 November 2015, authorizing Swing to reach out to the UN to renegotiate the IOM-UN relationship. ${ }^{33}$ The General Assembly responded in April 2016 by "Recognizing the need to establish a closer relationship" between the UN and IOM, and calling on the SecretaryGeneral to negotiate a new agreement with IOM, for voting at the next General Assembly session, making it a high-profile "deliverable" for the 2016 Summit on Refugees and Migration. ${ }^{34}$

$30 \quad$ McKinley 2007.

31 Ban 2007.

32 Interview, IOM official 14, December 2016.

33 IOM Council 2015.

34 UNGA 2016 (emphasis added). 
Despite IOM's rebranding as the UN Migration Agency, some argue that as a related organization IOM remains outside the UN system, contending that "although banners and leaflets may suggest otherwise, [IOM] is not a United Nations agency, and neither has it 'entered' or 'joined' the UN. It remains an inter-governmental organization, still outside the system, but in a 'closer relationship'" with it. ${ }^{35}$ This section examines the status of related organizations, demonstrating that politically and functionally IOM is now part of the UN system as the UN itself explains it, and denotes attitudinal shifts within IOM on the merits of this status.

How is the UN system to be conceived? What is the status of related organizations? The UN Charter does not explicitly define the "UN system" or the status of related organizations. However, Nigel White stresses that the "UN 'system' of organizations, organs and subsidiary bodies, agents, experts and employees is vast and diverse" and includes specialized agencies as well as related organizations. ${ }^{36}$ To understand the contours of the UN system, attention must be paid not only to the legal status of entities in the system, but also to the political realities created by how IOs position themselves and recognize one another, as directed by Member States.

Related organizations and specialized agencies are both legally autonomous from the UN itself, and are governed and funded independently of the UN's principal organs. However, the creation and status of specialized agencies is addressed in the UN Charter, with Article 57 stating that "various specialized agencies, established by intergovernmental agreement and having wide international responsibilities, as defined in their basic instruments, in economic, social, cultural, educational, health, and related fields, shall be brought into relationship with the United Nations in accordance with the provisions of Article 63." Under Article 63, the Economic and Social Council (ECOSOC) may conclude agreements to bring specialized agencies into relationship with the UN, with General Assembly approval. In contrast, the CEB indicates that "related organization" is "a default expression, describing organizations whose cooperation agreement with the United Nations has many points in common with that of Specialized Agencies, but does not refer to Article 57 and 63 of the United

35 Goodwin-Gill 2019. See also Pécoud 2018, 1632, 1622; Cullen 2019; Chetail 2019, 366.

36 White 2011, 298, 305; Rittberger 2002, 3. For an insightful discussion of the legal dimensions of IOM's position and the ambiguities of related organizations, see Chetail 2019, $360-397$. 
Nations Charter." ${ }^{37}$ Agreements for related organizations are approved directly by the General Assembly.

The related organizations are remarkably diverse, ranging from prominent IOs like the International Criminal Court (ICC), the World Trade Organization (WTO), and the IAEA to treaty secretariats such as the Organization for the Prohibition of Chemical Weapons and the Secretariat of the UN Framework Convention on Climate Change. ${ }^{38}$ Known as "UN Climate Change," the UN Secretariat describes the latter as "the United Nations entity tasked with supporting the global response to the threat of climate change."39 These entities conceptualize, communicate, and leverage their relationship to the UN system in strikingly different ways. For example, the 2004 Negotiated Relationship Agreement between the ICC and the UN confirms that as an "independent permanent institution" the court is "in relationship with the United Nations system" (emphasis added).$^{40}$ While some related organizations such as the WTO rarely address their UN links, for actors like UN Climate Change this is central to their place and influence in the international system. The related organizations are explicitly acknowledged by the UN's Member States, the UN Secretariat, and the CEB as part of the UN system. Reflecting this, eight of the most prominent related organizations - including IOM - appear on the UN Secretariat's official chart of the UN system. ${ }^{41}$ The Secretariat notes that the chart reflects the "functional organization of the United Nations system," suggesting the Secretariat itself distinguishes between particular entities' formal legal identity and position, and the question of which institutions are functionally part of the UN system as a practical matter and political enterprise. ${ }^{42}$

Is there a distinction between being in the UN system and being a UN agency per se? The position of the Office of the Legal Adviser in the US State Department is that legally related organizations and specialized agencies alike are separate institutions from the UN itself, and have independent legal personalities; on this view, "neither specialized agencies nor related organizations are part of 'the UN,' but they are part of 'the UN system.' In contrast, the funds and programmes are subsidiary bodies of the UN and do not have separate legal personality."43 While some disagree with this characterization, it is certainly

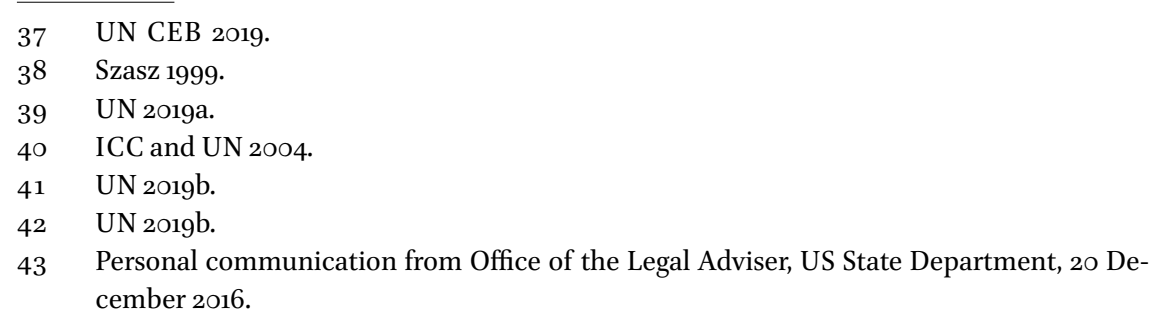


an influential view given the United States' prominence as a donor and power broker. ${ }^{44}$ Jan Klabbers lends support to this interpretation, writing that IOM's position "was further solidified when in 2016 it joined the UN family, a group of some 20 international organizations closely related to and co-operating with the United Nations." 45

What are the practical consequences of being part of "the UN" versus "the UN system" or "family"? Related organizations have less oversight from within the UN architecture than specialized agencies; for instance, related organizations are generally not obliged to report to the General Assembly, ECOSOC, or the Secretariat. The significance of whether an organization is formally part of the UN or simply in the UN system is shaped in large part by how organizations position and portray themselves, and how different actors interpret the consequences of these relationships for their obligations and activities.

Whether an organization becomes a related organization, a UN fund or program, or specialized agency depends on the substantive issue at hand, and the history, sensitivities, and specifics of the organization's work. Broadly, states have refused to establish funds or programs when they want to avoid direct funding obligations, or more directly govern an organization. Some IOM leaders thought becoming a specialized agency was superior to related organization status, indicating that "seeking a related agency status whose contours are still ill defined would be more confusing than helpful."46 However, perspectives shifted along with institutional interests and Member States' views. By becoming a related organization, IOM was able to address its primary concerns regarding its relationship with the UN, without ruffling its Member States. Although some debates continue around the status of related organizations, from the perspective of many practitioners within the UN and IOM, the practical upshot of the 2016 decision is clear: as a former UNHCR executive put it, "They are in the UN, they're called the UN Migration Agency, and they'll be invited to all the key forums." ${ }^{47}$ Another UN humanitarian official reflected, "They're seen as in the system ... [IOM is] seen as part of the UN family, I don't think people really distinguish." ${ }^{48} \mathrm{Or}$, in the words of a senior IOM official involved in the 2016 negotiations, "IOM is part of the system. Period."49

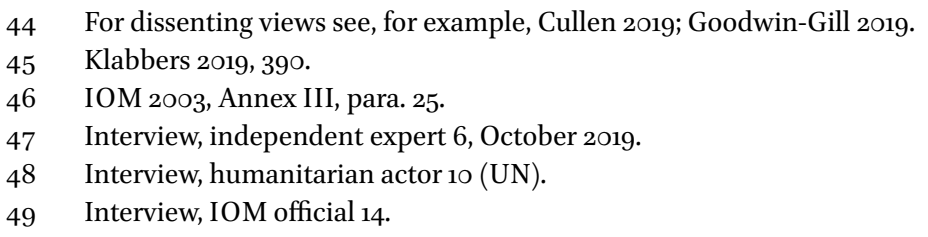


In February 2016, Swing wrote to Ban to communicate IOM Member States' wish to change the IOM-UN relationship, identifying three options: make IOM a specialized agency, a related organization, or negotiate a sui generis agreement. ${ }^{50}$ The IOM Council approved the draft agreement in June 2016 and the General Assembly in July 2016, followed by the signing ceremony at the September summit.

In his signing ceremony speech, Swing said three factors motivated IOM's entry into the UN system: first, migration dynamics-especially massive humanitarian crises - required a robust international response, facilitated by IOM becoming a related organization. Second, the timing was decisive: 2015 witnessed a perceived migration crisis, and the passage of major migration and displacement-related agreements including the UN Sustainable Development Goals, the World Humanitarian Summit outcome documents, and the Paris climate change agreement. Bringing IOM into the UN system would, Swing argued, advance efforts to implement these agreements. Last, in Swing's view, the agreement simply "formaliz[ed] an old relationship" as "we have collaborated so closely that we have continued to think of ourselves as UN in many ways." 51

Unsurprisingly, the motivations for this change, and views on it, are more complicated. These drivers were influential, but they shaped the process in ways unrecognized at the signing ceremony. One glaring concern was the desire to claim and defend institutional turf. By 2016, it was clear that the UN system needed a migration-focused agency, and IOM wanted to avoid the creation of a competitor institution. IOM's interests were aligned with donors loath to fund a new, overlapping body. Almost thirty UN entities engage on migration in various ways, but because none focused primarily on migration they were illpositioned to take a leading role, especially operationally. This made it appear logical to facilitate IOM's entry into the UN system.

Regarding timing, the 2016 summit itself was pivotal, especially to the decision to make IOM a related organization, not a specialized agency. Quickly hammering out the agreement responded to the perceived "need for some low hanging fruit" to demonstrate progress from the summit. ${ }^{52}$ As it became clear that the summit would initiate the multiyear Global Compact on Migration

50 Guild, Grant, and Groenendijk 2017, 7.

$51 \quad$ Swing 2016.

$5^{2}$ Interview, IOM official 14. 
process, the push to bring IOM into the UN system gained momentum, so that IOM could support the negotiations - the general perception being that they should be facilitated from within the UN system. Making IOM a specialized agency would have required going through ECOSOC, extending the process and potentially compromising the September summit deadline. The negotiators therefore chose the speedier option of making IOM a related organization.

\subsection{Member State Perspectives}

Beyond turf and timing issues, the 2016 decision was decisively shaped by Member States' perspectives. The expansion of IOM's membership base was essential to marshaling political support for this change. In 2003, IOM's small pool of members was a barrier to joining the UN system. IOM counted ninetyeight members in 2003; five large powers—China, Russia, India, Indonesia, and Brazil—were only observers, and IOM had almost no Middle Eastern members. ${ }^{53}$ IOM gradually and strategically persuaded new states to join, such that by 2016 almost all UN Member States also belonged to IOM. IOM concertedly cultivated champions for its work among donor countries and major migrantsending states, many of which were especially active supporters of IOM entering the UN system. Consequently, once the issue was decided among IOM's members, the only significant remaining hurdles came from the UN bureaucracy. Since influential governments, especially the United States, supported IOM's repositioning, UN opposition was dramatically curtailed.

Certainly, when Swing relaunched discussions on IOM-UN relations, the Member States were far from unified. Given the United States' historically dominant role within IOM (and its influence in the UN), many governments wanted the United States to signal its position before solidifying their own. Washington's traditional stance was, as one official put it, "Never, over our dead body, will IOM join the UN." ${ }^{54}$ However, Swing offered arguments for reform that the Barack Obama administration found persuasive, particularly regarding the possibility of responding more effectively to vulnerable migrants in crises, without compromising IOM's efficiency and cost-effectiveness. ${ }^{55}$ With US support secured, other governments agreed to back the change.

Hurdles also emerged because many IOM members engage with IOM through their Interior Ministries, rather than their Ministries of Foreign Affairs. Compared to diplomats inclined to value multilateralism, many Interior Ministry officials perceive the UN as interfering, impractical, and bureaucratically

$53 \quad$ IOM 2003, Annex 1, para. 59.

54 Interview, Member State official 5, December 2016.

55 Interviews, Member State officials 4, 5, and 7, December 2016. 
inflated, and were concerned that joining the UN system would undermine IOM's efficiency and flexibility. ${ }^{56}$ Given such concerns, IOM's members placed clear parameters on Swing's negotiating remit. They supported IOM's inclusion in UN field operations and coordination and planning bodies, but required that IOM not sacrifice the qualities they prized, including its independence, efficiency, responsiveness, and purportedly non-normative character.

\subsection{Divergent Perspectives within IOM}

With IOM's members insisting that entry into the UN system not compromise its distinctive institutional characteristics, the challenge became how to preserve these characteristics while locating IOM within the UN system. IOM officials themselves were split on the desirability, and possibility, of this move. Many saw joining the UN system as part of IOM "growing up," and a means of accruing influence in policy debates and operations. Others saw clear costs in entering the UN system and were ambivalent. As one staff member reflected, "If IOM is unique and needs to be preserved, then probably the UN is not the best road for it." ${ }^{57}$ Some were concerned that joining the UN system would undermine the agency's operational focus and "turn us into bureaucrats." 58 In one staffer's view, IOM's extensive involvement in the UN-dominated humanitarian system means that integration is "an unavoidable part of growing up"; yet "there are aspects of our work that we would lose ... so it's not just a win-win game. ... The last thing the world needs is another agency that [just] organizes meetings. If we lose the operations, then we're really screwed."59 Perspectives on the value of becoming a related organization depend on different interests and positions within IOM, with support for IOM's entry into the UN system more pronounced among younger generations of staff who are seen to place greater value on working in partnership and in active support of migrants' rights.

\subsection{Divergent Perspectives within the UN}

During the 2016 negotiations, there was little public or open debate on the issue within or between UN agencies. Instead, while attention was focused on the global migration and refugee crisis, a relatively small group of high-level players settled the details, following the broad parameters set by states. Perspectives within the UN were by no means unified. For some, long-standing

\footnotetext{
$5^{6}$ Interview, IOM official 2, November 2015; Interview, IOM official 21, February 2020.

57 Interview, IOM official 13, November 2015.

$5^{8}$ Interview, IOM official 11, November 2015.

59 Interview, IOM official 9, November 2015.
} 
experiences working with IOM in humanitarian operations provided a degree of reassurance, whereas for others they evoked qualms. Senior officials from the UN Office for the Coordination of Humanitarian Affairs (OCHA) generally supported IOM's entry into the UN system - a position motivated in part by the sense that IOM was already operating like a "full UN agency" in various humanitarian contexts, making the process largely a "formality." 60 For UNHCR, collaborative missions such as the response to the 2011 Libyan revolution showed the potential for interagency cooperation, particularly regarding vulnerable migrants who are not refugees. However, some UN officials had deep concerns about the move. Particularly within UNHCR and the Office of the UN High Commissioner for Human Rights (OHCHR), there were "traditional concerns" about "IOM's protection bloodstream,"61 its lack of a formal protection mandate, and its readiness to question categories and definitions related to protection such as UNHCR's distinction between refugees and migrants. Some had abiding concerns about IOM's protection record, but suggested that excluding IOM because it lacks a formal protection mandate discounts IOM's progress in integrating protection standards into its policies and programming, and minimized UNHCR's own repeated protection failures. ${ }^{62}$ UN officials also questioned IOM's projectized structure-explicitly preserved in the 2016 agreement - and its competitive approach, concerned that its "pay for play" model leads IOM to undertake work incongruous with the purposes and principles of the UN.63 According to some UN officials, the projectization model fosters unreliability and competition, pushing IOM to "over-commit and under-deliver." ${ }^{\prime 4}$ Nonoperational agencies, particularly the UN Department of Economic and Social Affairs (UN DESA), which is involved in migration research and statistics, also expressed concerns about competition and institutional overreach. UN DESA steadfastly opposed IOM's self-portrayal as the leading IO working on migration, and jockeyed for increased recognition for its own work. ${ }^{65}$ Its concerns are reflected in the 2016 agreement in which the UN awkwardly recognizes IOM as "an organization with $a$ global role in the field of migration," while conceding that IOM's Member States regard IOM "as the global lead agency on migration." 66

\footnotetext{
6o Interview, humanitarian actor $10(\mathrm{UN})$.

61 Interview, humanitarian actor $1(\mathrm{UN})$.

62 Interviews, humanitarian actors 10 and 12 (UN); interview, human rights advocate 13 (UN).

63 Interviews, humanitarian actors 9 and 11 (UN).

64 Interviews, humanitarian actors $7,1,2$, and $11(\mathrm{UN})$.

65 Interviews, independent experts 2 and 6; interview, Member State official 4, December 2016.

66 Article 2.1 (emphasis added).
} 
Although these concerns generated some "backdoor resistance," the move garnered high-level support within the UN, particularly from the SecretaryGeneral, the High Commissioner for Refugees, and OCHA leadership. ${ }^{67}$ These actors recognized the changed will of powerful states, especially the United States, regarding IOM's status, the need for the UN system to have dedicated, operational capacity on migration, including regarding the Global Compact on Migration, and donors' unwillingness to fund a new entity. Reportedly, among some leaders there was also optimism that, if brought into the UN system, IOM could be more easily prevailed on to adopt and abide by the UN's norms. This high-level support and political momentum for a rapid repositioning of IOM as a related organization in time for the New York summit overwhelmed the opposition within some UN quarters.

The Agreement Concerning the Relationship between the United Nations and the International Organization for Migration

What has changed as a result of the 2016 agreement? Like the 1996 Cooperation Agreement, the 2016 agreement encourages cooperation in sharing information, expertise, research and statistics, promoting efficient administration, and avoiding the duplication. Further, the 2016 agreement provides for reciprocal, nonvoting representation and participation in governance bodies; allows IOM staff to use the UN laissez-passer; and establishes IOM as a full, formal member of the CEB, UNDG, IASC, and all UN country and regional teams. On some readings, these changes are modest as IOM was already part of many UN mechanisms. ${ }^{68}$ Yet the agreement gives IOM the status and recognition it has long sought, confirms its leadership role on migration issues, and clears legal and bureaucratic obstacles to its continued growth. The agreement may curtail some migration-related work previously undertaken by others in the UN system, and hem in IOM activities that are in tension with international human rights and refugee law, as IOM pledges in the agreement to abide by these standards, and the purposes and principles of the UN Charter.

As Swing's negotiating mandate required that the new relationship retain the "essential elements" of IOM's institutional character, the agreement's significances lies not only in what it creates but also in what it preserves. The

67 Interviews, humanitarian actors 10 and $9(\mathrm{UN})$; interview, independent expert 6; interview, IOM officials 16 and 19 .

68 Micinski and Weiss 2016, 2. 
agreement reflects Member States' vision of IOM as a "non-normative organization with its own constitution and governance system, featuring a predominantly projectized budgetary model and a decentralized organizational structure"; its distinctive characteristics include "responsiveness, efficiency, cost-effectiveness and independence" (Article 2.a). In reiterating language from Resolution 1309, including the contested "non-normative" characterization, the agreement implies that IOM and its members want to play the game both ways: they are eager for IOM to have the influence and gravitas associated with the UN; many IOM and government officials want IOM to more actively and reliably advance migrants' rights and, in some senses, the agreement provides a stronger basis for this. Yet they want these benefits without giving up characteristics that have facilitated IOM's involvement in disreputable and even dangerous behavior. In this way, the agreement doubles down on the tensions that have shaped IOM and its role in the international system since its creation.

\subsection{A "Non-normative" Agency?}

On Member States' insistence, Resolution 1309 and the 2016 agreement both characterize IOM as a "non-normative" organization. ${ }^{69}$ Previously, this term was not common to discourse around IOM; its deployment has generated concerns that it may legitimize actions incompatible with the values of the UN system..$^{70}$ "Non-normative" is not a legal term of art. On a certain level it is nonsensical to describe any IO as non-normative in that they are all, in different ways, shaped by and involved in the transmission of various norms. Scholarship on international norms and IOs often focuses on the spread and influence of "good" norms such as "protecting the environment, enhancing human rights, and controlling the spread and use of heinous weapons." ${ }^{71}$ However, IO s may promote norms that sit uneasily with such positive norms such as the principle of respect for state sovereignty and nonintervention. IOM is a case in point. Despite its non-normative designation, IOM has developed a raft of new policies, guidelines, and frameworks that-in the absence of a constitutionally enshrined protection mandate-articulate its perspectives on and commitments regarding human rights and humanitarian principles. These include two overarching institutional frameworks, the 2012 Migration Crisis Operational Framework and the 2015 Migration Governance Framework, as well as institutional standards such as the IOM Policy on Human Rights and

69 Interview, IOM official 2; Interview, Member State official 1.

70 Guild, Grant, and Groenendijk 2017,14.

$71 \quad$ Legro 1997, 31. 
Migration (2009), the IOM Humanitarian Policy (2015), the Progressive Resolution of Displacement Situations Framework (2017), and the Framework for Addressing Internal Displacement (2017). Alongside its (still halting) efforts, as reflected in these documents, to internalize and externally advance positive human rights and humanitarian norms, IOM has assertively backed the norm of virtually unfettered state sovereignty in admitting foreign nationals and a range of related migration management norms. On some accounts IOM has been the "biggest driver" of recent norm-setting efforts on international cooperation on migration. ${ }^{72}$ These norms defy easy categorization as good or bad, in that they typically increase mobility for privileged populations, while constraining those deemed less deserving or desirable — which, depending on political and moral perspectives, may be seen as laudable or profoundly unjust. IOM's designation as non-normative is particularly curious as the very day that Ban and Swing signed the 2016 agreement, states tapped IOM to support the Global Compact on Migration process. While this process did not aim to create binding law, it was undoubtedly normative in the broad sense of providing guidance and clarifying shared "standards of behavior defined in terms of rights and obligations."73

How, then, should this designation be understood? During the negotiations, "non-normative" took on a particular connotation among the IOM administration and Member States: that IOM would not be a venue for creating binding international norms on migration, in the way the International Labour Organization does on labor standards, for example. Interpreted from this vantage, IOM's role in processes such as the Global Compact on Migration is fitting as the compact is not binding. On some levels, IOM's non-normative designation can be read analogously to UNHCR's characterization as "nonpolitical" in its statute. Such words can have serious consequences. ${ }^{74}$ UNHCR has sometimes used its nonpolitical designation to avoid challenging refugeeabusing governments, and IOM may hide behind the "non-normative" term. Yet these words are powerful in part because they enable useful fictions: UNHCR is clearly political, in that recognizing, assisting, and protecting refugees are deeply and inescapably political tasks demanding political savvy. UNHCR is nonpolitical in the narrower, humanitarian sense or not taking sides in war or partisan politics. Characterizing UNHCR as nonpolitical was critical to its creation amid Cold War divisions, and has required that High Commissioners

72 Ferris and Donato 2019, 70.

73 Krasner 1982, 186.

74 Forsythe 2oo1; Bradley 2020. 
tread a careful path in executing their mandate. Similarly, labeling IOM "nonnormative" seems inconsistent with its acknowledged role in the 2016 agreement (Article 2.2) as an "essential contributor ... in the protection of migrants." Its activities have inherently normative dimensions, much as UNHCR's work has inescapably political dimensions, and it was a relatively narrow interpretation of "non-normative" (i.e., not setting binding international standards) that informed the 2016 negotiations. To be sure, interpretations of this designation, and its consequences, may change and require close monitoring. However, this analysis suggests the term should be understood in its political and historical context.

The full implications of IOM's entry into the UN system remain uncertain, and opinions are divided on its import. In some ways IOM continues with its business as usual, reflecting its significant prior imbrication with the UN system. As one senior UN humanitarian official expressed it, "IOM was de facto already a UN agency."75 Moving forward, the differences may be most evident regarding IOM's engagement in development activities, as it was already extensively engaged in UN humanitarian country teams, with humanitarian cooperation providing a critical foundation for the organizations' evolving relationship.

Continuing business as usual is more significant than it may appear, as recent decades have witnessed dramatic growth and increased prominence for IOM; becoming a related organization enables IOM to sustain further growth. Critically, the 2016 agreement means that IOM's anticipated expansion will take place inside the UN system. This may constrain some contentious work, and help other parts of IOM to expand. For instance, some officials indicate IOM's humanitarian efforts have been compromised by controversial migration management activities that have raised protection concerns and undermined IOM's claimed humanitarian credentials. Others caution that IOM's UN links may "blue wash" its work; that is, its affiliation with the UN as an institution with a long (if imperfect) history of commitment to human rights and humanitarian principles may give even ethically dubious or rights violative activities an imprimatur of legitimacy. ${ }^{76}$ This is a risk that demands continued attention.

75 Interview, humanitarian actor 9 (UN).

76 Hirsch and Doig 2018. 
While IOM continues in some ways with business as usual, in other senses its entry into the UN system has already entailed some significant changes. IOM's visibility within the UN system has increased markedly owing to its involvement in the Global Compact on Migration-a role it could play because it joined the system. It has accepted important coordination mantles, most notably as the secretariat for the new UN Network on Migration. IOM is reportedly increasingly assertive in its coordinating roles; now that the agency is "within the circle," it is integrated into key decision-making forums and leveraging opportunities to shape system-level policies. ${ }^{77}$ Some suggest that confidence and morale have increased within IOM, with staff proud to travel on the blue UN laissez-passer. ${ }^{78}$ As one observer expressed it, "It's a step up. ... It's like a university joining the Ivy Leagues, it makes a big difference to them in terms of their morale." 79

The move has also bolstered IOM's acknowledged legal obligations and, in some senses, its engagement on protection. Since becoming a related organization, the IOM Legal Office has concluded that the organization is now obligated to uphold all the common laws and principles that bind UN agencies. ${ }^{80}$ IOM now participates in the UN's Human Rights Up Front initiative, and is obliged to support the implementation and monitoring of the UN's mandatory Human Rights Due Diligence Policy, which may have important implications for its work in countries like Libya. ${ }^{81}$ Since 2016 IOM has also invested in more seniorlevel protection expertise at its headquarters, in part to increase its ability to realize the commitments and obligations that have come with entering the UN system. ${ }^{82}$ More generally, IOM's use of human rights discourse has become more pronounced since 2016, and more explicitly tied to the expectations of actors in the UN system. For example, IOM's Strategic Vision for 2019-2023 reiterates its commitment to the "principles enshrined in the Charter of the United Nations, including upholding human rights for all." ${ }^{83}$ While human rights advocacy organizations such as Amnesty International and Human Rights Watch intensively monitor UN agencies such as UNHCR, they have devoted much less attention to IOM and were largely silent on IOM's entry into the UN system. Whether IOM entering the UN system generates more concerted attention and

77 Interview, humanitarian actor 10 (UN), September 2019; Interview, independent expert 6.

78 Interview, IOM official 15, January 2018.

79 Interview, independent expert 6.

8o Interview, IOM official 17, December 2019; Interview, IOM official 19, January 2020.

81 Interview, IOM official 17, December 2019; Interview, IOM official 19, January 2020.

82 Interview, IOM official 17, December 2019; Interview, IOM official 19, January 2020.

83 IOM 2o19b, ii. 
pressure from these actors remains to be seen. In theory, however, these watchdog groups could help hold IOM to account for its obligations as part of the UN system.

Membership in the UN system also presents new challenges for IOM. The agency has to prove to its Member States the continued value of its work within the UN system, and differences in working cultures, mandates, and approaches must be navigated. The 2016 agreement stresses that IOM is to maintain its projectized structure, but some leaders inside and outside the agency are hopeful that IOM's entry into the UN system may help it diversify its funding streams, and move away from being so project dependent. ${ }^{84}$ Some suggest that there is now increased scope for cooperation with UNHCR, including on the protection of vulnerable migrants who are not refugees, and some more collaborative approaches have already emerged such as UNHCR and IOM's deployment of a joint envoy to address the exodus from Venezuela. ${ }^{85}$ Yet on some levels, relationships with UN entities such as UNHCR and UN DESA continue to be tense and competitive, underscoring the need to ensure IOM staff are trained to work effectively in an environment in which partnership must be a more significant part of the institution's modus operandi than it has been in the past. ${ }^{86}$ Hopes for improved cooperation were raised further when Portuguese politician António Vitorino was elected IOM Director General in October 2018, given his service in the government of António Guterres, now UN Secretary-General. These developments imply that patterns of rapprochement and integration, alongside unresolved tensions, will keep shaping IOM-UN relations, and merit continued close analysis.

\section{Bibliography}

Andrijasevic, Rutvica, and William Walters. "The International Organization for Migration and the International Government of Borders." Environment and Planning D: Society and Space 28 (6) (2010), 977-999.

Ashutosh, Ishan, and Allison Mountz. "Migration Management for the Benefit of Whom? Interrogating the Work of the International Organization for Migration." Citizenship Studies 15 (1) (2011), 21-38.

Ban, Ki-moon. Letter to IOM Director General Brunson McKinley, 8 October 2007.

84 Interview, IOM officials 16, 19, and 21; Interview, independent expert 6.

85 Interview, humanitarian actor $11(\mathrm{UN})$, November 2019.

86 Interview, IOM official 14. 
Bradley, Megan. “The International Organization for Migration (IOM): Gaining Power in the Forced Migration Regime." Refuge 33 (1) (2017), 97-106.

Bradley, Megan. The International Organization for Migration: Commitments, Challenges, Complexities (London: Routledge, 2020).

Chetail, Vincent. International Migration Law (Oxford: Oxford University Press, 2019).

Cordier, Andrew. Letter from Andrew Cordier, Executive Assistant to UN SecretaryGeneral

Dag Hammarskjöld, to Martin Hill, Deputy Under-Secretary for Economic and Social Affairs, 19 February 1957. UN Headquarters Archive File \#391 ICEM, S-o369-oo3o-o6.

Cullen, Miriam. "The IOM's New Status and Its Role under the Global Compact for Safe, Orderly and Regular Migration: Pause for Thought." EJIL: Talk! 29 March 2019.

Ducasse-Rogier, Marianne. The International Organization for Migration: 1951-2001 (Geneva: IOM, 2001).

Élie, Jérôme. "The Historical Roots of Cooperation between the UN High Commissioner for Refugees and the International Organization for Migration." Global Governance 16, (3) (2010), 345-36o.

Ferris, Elizabeth, and Katharine Donato. Refugees, Migration and Global Governance: Negotiating the Global Compacts (London: Routledge, 2019).

Forsythe, David. “UNHCR's Mandate: The Politics of Being Non-Political." UNHCR New Issues in Refugee Research 33 (2001), 1-34.

Georgi, Fabian. "For the Benefit of Some: The International Organization for Migration and Its Global Migration Management." In The Politics of International Migration Management, eds. Martin Geiger and Antoine Pécoud (Basingstoke: Palgrave, 2010), 45-72.

Goodwin-Gill, Guy. "A Brief and Somewhat Sceptical Perspective on the International Organization for Migration." 7 April 2019. https://www.kaldorcentre.unsw.edu.au/ publication/brief-and-somewhat-sceptical-perspective-international-organization -migration. (Kaldor Centre for International Refugee Law).

Gregg, Robert, and Michael Bakin, eds. The United Nations System and Its Functions (Princeton, NJ: Van Nostrand, 1968).

Guild, Elizabeth, Stefanie Grant, and Kees Groenendijk. "IOM and the UN: Unfinished Business." Queen Mary University of London School of Law Legal Studies Research Papers 255 (2017), 1-24.

Hammarskjöld, Dag. Letter from UN Secretary-General Dag Hammarskjöld to ICEM Director General Hugh Gibson, 3 August 1953. UN Headquarters Archive File \#391 ICEM, S-o369-oo3o-o6.

Hill, Martin. Letter from Martin Hill, Deputy Under-Secretary for Economic and Social Affairs, to UN Secretary-General Dag Hammarskjöld, 4 August 1953. UN Headquarters Archives File \#391 ICEM, S-o369-oo3o-o6.

Hill, Martin. Memo to UN Secretary-General Dag Hammarskjöld from Martin Hill, 
Deputy Under-Secretary for Economic and Social Affairs, 9 March 1956. UN Headquarters Archive File \#391 ICEM, S-o369-oo3o-o6.

Hirsch, Asher, and Cameron Doig. "Outsourcing Control: The International Organization for Migration in Indonesia." International Journal of Human Rights 22 (5) (2018), $681-708$.

ICC (International Criminal Court) and UN. Relationship agreement between the United Nations and the International Criminal Court, A/58/874, (2004).

IOM (International Organization for Migration). IOM Strategic Planning: Toward the Twenty-first Century. 71st session of IOM Council, 9 May 1995, MC/1842.

IOM. IOM-UN Relationship: Summary Report of the Working Group on Institutional Arrangements. 86th session of IOM Council, 1o November 2003, MC/INF/263.

IOM. Options for the IOM-UN Relationship: Additional Analysis of Costs and Benefits. 94th session of IOM Council, 9 November 2007, MC/INF/29o.

IOM. IOM Snapshot 2019 (Geneva: IOM, 2019a).

IOM. IOM Strategic Vision 2019-2023: Setting a Course for IOM. 15 November 2019b, $\mathrm{C} / \mathbf{1 1 0} / \mathrm{INF} / \mathbf{1}$.

IOM Council. IOM-UN Relations, Resolution 1309. C/106/RES/1309 (2015).

Klabbers, Jan. "Notes on the Ideology of International Organizations Law: The International Organization for Migration, State-Making and the Market for Migration." Leiden Journal of International Law 32 (3) (2019), 383-40o.

Koch, Anne. "The Politics and Discourse of Migrant Return: The Role of UNHCR and IOM in the Governance of Return." Journal of Ethnic and Migration Studies 40 (6) (2014), 905-923.

Krasner, Stephen. "Structural Causes and Regime Consequences: Regimes as Intervening Variables." International Organization 36 (2) (1982), 185-205.

Legro, Jeffrey. "Which Norms Matter?" International Organization $5^{1}$ (1) (1997), 31-63.

Martin, Susan. International Migration: Evolving Trends from the Early Twentieth Century to the Present (Cambridge: Cambridge University Press, 2014).

McKinley, Brunson. Statement by the Director General at the Eighty-fourth Session of the Council, 2-4 December 2002, MICEM/7/2002.

McKinley, Brunson. Letter to UN Secretary-General Ban Ki-moon, 10 July 2007.

Micinski, Nicholas, and Thomas Weiss. "International Organization for Migration and the UN System: A Missed Opportunity." Future UN Development System Briefings 42 (2016), $1-4$.

Pécoud, Antoine. "What Do We Know about the International Organization for Migration?" Journal of Ethnic and Migration Studies 44 (10) (2018), 1621-1638.

Rittberger, Volker. Global Governance and the UN System (Tokyo: United Nations University Press, 2002).

Swing, William. "Statement at the September Summit and Signing of the IOM-UN Agreement." 19 September 2016 (New York). 
Szasz, Peter. "The Complexification of the United Nations System." Max Planck Yearbook of United Nations Law 3 (1999).

White, Nigel. The United Nations System: Toward International Justice (Boulder: Lynne Rienner, 2002).

White, Nigel. "Layers of Autonomy in the UN System." In International Organizations and the Idea of Autonomy: Institutional Independence in the International Legal Order, eds. Richard Collins and Nigel White (London: Routledge, 2011), 298-315.

UN. "Funds, Programmes, Specialized Agencies and Others." 2019a. http://www.un .org/en/sections/about/funds-programmes-specialized-agencies-and-others/index .html.

UN. "The United Nations System.” 2019b. https://www.un.org/en/pdfs/18-oo159e_un _system_chart_17x11_4c_en_web.pdf.

UN CEB (UN Chief Executives Board for Coordination). "Directory of United Nations System Organizations: Related Organizations." 2019. https://www.unsystem.org/me mbers/related-organizations.

UNGA (UN General Assembly). Cooperation between the United Nations and the International Organization for Migration, Resolution 70/263, UN Doc. A/RES/70/263 (2016).

UNSG (UN Secretary-General). Strengthening the United Nations: An Agenda for Further Change, Report of the Secretary-General. UN Doc. A/57/387 (2002). 